\title{
Seedling Blight Development and Control in Spring Wheat Damaged by Fusarium graminearum Group 2
}

\author{
R. K. Jones, Associate Professor and Extension Plant Pathologist, Department of Plant Pathology, University of \\ Minnesota, St. Paul 55108
}

\begin{abstract}
Jones, R. K. 1999. Seedling blight development and control in spring wheat damaged by Fusarium graminearum group 2. Plant Dis. 83:1013-1018.

Aspects of seedborne infection in Fusarium-damaged and undamaged seed lots of hard red spring wheat were studied. In a $22^{\circ} \mathrm{C}$ environment, seedling blight developed from plantings of Fusarium-damaged seed that were characterized by both reduction and delay in emergence and postemergence seedling death. After 28 days, stand counts from the Fusarium-damaged seed lot averaged $46 \%$, compared with $98 \%$ from the undamaged seed lot. However, the mean dry weight of surviving seedlings from the Fusarium-damaged lot was not statistically different from that of seedlings from the undamaged seed lot. Surface-sterilization reduced recovery of Fusarium graminearum group 2 from the damaged lot by $7 \%$ and increased germination by $32 \%$, suggesting that seed are both infected and contaminated with viable propagules of the fungus. In field experiments, seed treatment with maneb- or thiabendazole-containing fungicide combinations significantly reduced seedling blight and improved stands derived from the Fusarium-damaged seed lot. Triazole fungicides, including difenoconazole, fenbuconazole, and tetraconazole, were less effective. Triazole fungicides and carboxin-containing fungicide combinations controlled loose smut in these trials, while maneb seed treatments did not. In four field tests, seedling blight incidence in plantings of Fusarium-damaged seed increased as soil temperatures during emergence increased. The distribution of blighted seedlings was random and not clustered. Seedling blight did not develop in field plantings of the undamaged seed lot.
\end{abstract}

Additional keywords: chemical control, Gibberella zeae

Hard red spring wheat (Triticum aestivum) in the north central region of the United States has been affected in recent years by epidemics of Fusarium head blight (FHB). Severe outbreaks developed in 1993 and $1994(15,19)$ and again in 1997. In Minnesota, FHB is primarily caused by Fusarium graminearum group 2 (Gibberella zeae), although other Fusarium species have been recovered from infected plant parts (33). Seed obtained from fields within FHB-affected areas exhibits characteristic signs and symptoms of Fusarium damage $(3,4)$. Seed lots are often mixtures of visually damaged kernels, kernels that are infected but not visibly damaged, and uninfected, undamaged seed (16). Concern exists about the suitability of such seed for planting purposes. Seed of adapted cultivars is often produced locally within the region, and the widespread nature of recent FHB epidemics limits the availability of unaffected seed.

Fusarium species that attack the roots and crowns of wheat include $F$. culmorum

Corresponding author: R. K. Jones
E-mail: rogerj@ puccini.crl.umn.edu

Accepted for publication 13 July 1999.

Publication no. D-1999-0902-01R

(C) 1999 The American Phytopathological Society
(8) and F. graminearum group 1 (11). Although occasionally recovered from seed (21), these fungi lack a functional ascigerous stage, are adapted to survival in the soil (28), and are widely distributed in the more arid regions of the United States $(8,28,29)$. F. culmorum is rarely identified as a component of the FHB complex affecting wheat in Minnesota $(16,33)$, and $F$. graminearum group 1 was not identified in recent studies of crown rot $(34,35)$.

Seedling blight associated with $G$. zeae has been described by various authors, including Atanasoff (3), Dickson $(9,10)$, and more recently by Bergstrom (5). The interaction of the anamorphic stage with germinating seed is described by HalfonMeiri et al. (14). Damage caused by the fungus is expressed in loss of germinability, reduced emergence, and a postemergence blight of seedlings. Seedling blight develops over a broad temperature range, but damage is greatest at temperatures between 20 and $28^{\circ} \mathrm{C}(9,14)$.

Seed treatments reduce the activity of $F$. graminearum $(6,7,12,18,20)$, although growers in Minnesota often report that benefits from planting treated seed are not consistent and that germination tests are not reliable indicators of seed lot performance. Some variability may be due to the reported decrease in viability of $F$. graminearum in stored seed over time $(5,13)$. Four to five months may elapse between fall (October to November) germination testing of seed lots and the April to May planting of spring wheat in the Upper Midwest. Temperature variation during emergence (warm versus cool) may also represent a factor contributing to variation in seed lot performance (12). Bergstrom (5) discusses the difficulties encountered by seed testing services in evaluating the results of blotter tests and estimating field performance of Fusariumdamaged seed lots. Official test procedures (2) include blotter assay protocols of $20^{\circ} \mathrm{C}$ $(16 \mathrm{~h}) / 16^{\circ} \mathrm{C}(8 \mathrm{~h})$ incubation. These temperatures are lower than those reported as optimal for the expression of seedling blight (14).

Spring wheat producers in Minnesota usually treat seed with carboxin-containing fungicides to control loose smut (caused by Ustilago tritici). Carboxin is typically combined in two-way or three-way combinations with imazalil or thiram to broaden the spectrum of activity (26). Imazalil is registered to control seedborne and soilborne phases of common root rot (caused by Bipolaris sorokiniana). Seed treatment fungicides containing ethylene bis dithiocarbamates (such as maneb or mancozeb) are also registered for use in spring wheat (26). In Minnesota, these are frequently used as two-way mixtures with the insecticide lindane for temporary protection against wireworms. Recently, new threeway combinations containing carboxin, imazalil, and thiabendazole (Vitavax-Extra) and broad-spectrum triazole fungicides including difenoconazole (Dividend) have become registered for use on spring wheat seed.

The purpose of this study was to compare and contrast the quality and performance characteristics of two seed lots of hard red spring wheat from Fusariumdamaged (1993) and -nondamaged (1992) sources. Seed lots examined in this study were selected to represent extreme differences in their degree of damage. Another purpose was to evaluate the efficacy of currently registered and selected experimental seed treatments on seedling blight, stand establishment, loose smut, and yield.

\section{MATERIALS AND METHODS}

Seed lot quality. The study involved two lots of hard red spring wheat cv. Norm produced in the Red River Valley of Minnesota in 1992 and 1993 (Table 1). Norm is considered highly susceptible to FHB 
$(15,16)$. Seed had been commercially cleaned and was used as submitted by seed growers to the Minnesota Crop Improvement Association (MCIA) for certification. The 1992 source had been stored at $10^{\circ} \mathrm{C}$ and $50 \%$ relative humidity for 12 months prior to use in this study. Infection frequency was determined based on 100 sterilized or 100 unsterilized seed plated ( 5 per plate) on potato dextrose agar (PDA). Plates were incubated under continuous cool-white light for 7 days at $24^{\circ} \mathrm{C}$, and colonies of Fusarium spp. were identified using standard keys (22). Germination tests were conducted on blotters containing 100 seed incubated at $24^{\circ} \mathrm{C}$ for 7 days. Surfacesterilized and unsterilized treatment sets were assessed. Seed was surface-sterilized in $95 \%$ ethanol $(5 \mathrm{~s})$ followed by immersion in a solution of $0.5 \% \mathrm{NaOCl}$ for 1 min, then rinsed in sterile distilled water and dried. Vigor tests were conducted by planting 100 seed in flats of steam-sterilized soil incubated in controlled-environment chambers at $22^{\circ} \mathrm{C}$ for 28 days. Seedlings were counted at 7-day intervals during the tests. Fresh weight and dry weight were determined after 28 days. Intact seedlings were washed free of soil, placed in forced-air ovens at $95^{\circ} \mathrm{C}$ for $48 \mathrm{~h}$, and weighed. Tests for infection frequency, germination, and vigor were repeated six times each using 100 surface-sterilized and 100 untreated seed. $t$ tests were used in hypothesis testing for differences between seed lots.

Seed treatment. Seed lot 93-4843 (1993 produced, Fusarium-damaged source) and 92-0071 (1992 produced, undamaged source) were treated at registered rates with commercially formulated fungicides (Table 2). Key comparisons included Vitavax-Extra (a mixture of $27.8 \%$ carboxin, $2.5 \%$ thiabendazole, and $2.0 \%$ imazalil; Gustafson Inc., Dallas, TX) and DB-Green $\mathrm{L}$ (a mixture of $25.6 \%$ maneb and $8.6 \%$ lindane; Agsco Inc., Grand Forks, ND). Additional treatments were evaluated on the Fusarium-damaged lot 93-4843. Triazole fungicides tested included Dividend (a formulation containing $32.8 \%$ difenoconazole; Novartis Inc., Greensboro, NC), AG4452 (a formulation containing $0.425 \%$ fenbuconazole; Agsco), and AG-4454 (a formulation containing $0.425 \%$ tetraconazole; Agsco). Agsco RR (a formulation of $10 \%$ imazalil; Agsco) was also tested in combination with DB-Green L. Chemicals were mixed with water $(1: 15 \mathrm{vol} / \mathrm{vol}$ for the formulation of difenoconazole; 1:3 vol/vol for all others), applied as a misted slurry (Laboratory Seed Treater, Gustafson), and allowed to dry before planting. Experiments were established at the North-

Table 1. Characteristics of seed lots 93-4843 (Fusarium-damaged) and 92-0071 (undamaged) of spring wheat cv. Norm

\begin{tabular}{lcccccc}
\hline Seed lot & Source & Seed/kg $^{\mathbf{a}}$ & Seed/ha $^{\mathbf{b}}$ & $\begin{array}{c}\text { Germ. } \\
(\boldsymbol{\%})^{\mathbf{c}}\end{array}$ & $\begin{array}{c}\text { Test wt. } \\
\left(\mathbf{k g ~ m}^{\mathbf{3}}\right)\end{array}$ & $\begin{array}{c}\text { VSK } \\
(\boldsymbol{\%})^{\mathbf{d}}\end{array}$ \\
\hline $93-4843$ & 1993 harvest & 29,646 & $3,985,000$ & 49.0 & 840 & 24.2 \\
$92-0071$ & 1992 harvest & 27,234 & $3,661,000$ & 96.0 & 938 & 0.3 \\
\hline
\end{tabular}

${ }^{a}$ Number of seed per kilogram was determined from 10 replicate samples of 1,000 kernels.

${ }^{\mathrm{b}}$ Number of seed planted per hectare in field experiments.

${ }^{\mathrm{c}}$ Percent germination determined from 400 seed (50 seed replicated eight times incubated on blotters at $20^{\circ} \mathrm{C}$ for 7 days) by the Minnesota Crop Improvement Association (MCIA, St. Paul, MN).

${ }^{d}$ Percent visually scabby kernels estimated from six replicate samples using visual comparison standards (16). west Experiment Station, Crookston (two planting dates), the West Central Experiment Station, Morris, and the West Plant Research Farm, Roseau. These sites are separated north and south by a distance of approximately $360 \mathrm{~km}$ (Roseau north, Morris south, and Crookston between them). Planting dates were 20 April and 11 May (Crookston), 11 May (Morris), and 3 May (Roseau) in 1994. Plots $(1.5 \times 6.1 \mathrm{~m})$ were seeded at a rate of $134.5 \mathrm{~kg} / \mathrm{ha}$, and treatments were replicated six times in a randomized complete block design. The number of seed per $\mathrm{kg}$ was determined for each lot from gram weight conversions of ten 1,000-kernel counts. Soil temperature at $10-\mathrm{cm}$ depth was continuously recorded at each site.

Disease assessments. Plant stand was assessed 21 days after planting at the threeleaf stage from the inner six rows of each 10-row plot. Seedlings were counted from the middle $0.3 \mathrm{~m}$ of $0.9-\mathrm{m}$ row sections beginning at the front corner of each plot and sampling down and across rows at 0.9$\mathrm{m}$ intervals (total of six locations). Counts were combined for each plot and analyzed by analysis of variance. Tukey's honestly significant difference (1) was calculated at the alpha $=0.05$ level. Percent stand was calculated by dividing the number of surviving seedlings by the estimated number of seed planted and multiplying by 100 . Loose smut was assessed approximately 60 days after planting at Feekes (17) growth stage 10.5.2 (flowering-complete) by counting the number of plants with smutted heads per 12 row-meters (two outer rows in each plot). Smut infection was assumed to be seedborne (27) and therefore randomly distributed. Counts were then adjusted to percent smut infection based on stand counts and analyzed statistically. Plots were combine-harvested at maturity, dried to uniform moisture content, and yields were determined. The percent visu-

Table 2. Influence of seed treatments on stand, loose smut, yield, and percent visually scabby kernels on two planting dates for spring wheat, Northwest Experiment Station, Crookston, Minn., 1994

\begin{tabular}{|c|c|c|c|c|c|c|c|c|}
\hline \multirow[b]{2}{*}{ Treatment $(\mathrm{ml} / \mathbf{k g})$} & \multicolumn{4}{|c|}{ Planted 20 April } & \multicolumn{4}{|c|}{ Planted 11 May } \\
\hline & Stand $(\%)^{\mathrm{a}}$ & Smut $(\%)^{b}$ & Yield $^{c}$ & $\operatorname{VSK}(\%)^{\mathbf{d}}$ & Stand $(\%)^{\mathrm{a}}$ & Smut $(\%)^{b}$ & Yield ${ }^{\mathrm{c}}$ & $\operatorname{VSK}(\%)^{d}$ \\
\hline Vitavax-Extra (1.95) & 83.1 & 0.03 & 1,533 & 35.7 & 77.8 & 0.00 & 1,143 & 34.5 \\
\hline DB-Green L (3.24) & 85.8 & 2.36 & 1,452 & 35.2 & 73.8 & 1.89 & 1,109 & 33.3 \\
\hline DB-Green L (3.24) + Agsco RR (0.43) & 89.1 & 1.66 & 1,607 & 35.8 & 69.4 & 0.82 & 1,130 & 34.2 \\
\hline Dividend $(0.16)$ & 72.3 & 0.00 & 1,479 & 36.8 & 53.4 & 0.06 & 1,035 & 35.2 \\
\hline Dividend (0.32) & 79.2 & 0.00 & 1,614 & 36.7 & 58.5 & 0.02 & 1,008 & 36.2 \\
\hline Agsco-4452 (3.24) & 60.0 & 0.09 & 1,472 & 38.0 & 37.6 & 0.00 & 827 & 39.7 \\
\hline Agsco-4452 (4.54) & 66.6 & 0.04 & 1,325 & 37.2 & 38.4 & 0.03 & 760 & 40.0 \\
\hline Agsco-4454 (1.62) & 67.8 & 0.00 & 1,197 & 38.0 & 42.4 & 0.00 & 867 & 37.5 \\
\hline Agsco-4454 (3.24) & 69.6 & 0.00 & 1,325 & 38.5 & 54.4 & 0.00 & 901 & 36.3 \\
\hline Untreated lot 93 & 54.4 & 2.02 & 1,365 & 36.5 & 33.1 & 1.60 & 659 & 42.5 \\
\hline Vitavax-Extra lot 92 (1.95) & 97.3 & 0.06 & 1,493 & 35.7 & 90.3 & 0.00 & 1,095 & 33.7 \\
\hline DB Green - L lot 92 (3.24) & 93.6 & 0.90 & 1,493 & 37.2 & 89.6 & 0.60 & 1,088 & 33.0 \\
\hline Untreated lot 92 & 98.0 & 0.84 & 1,513 & 36.8 & 96.7 & 0.68 & 1,095 & 33.7 \\
\hline $\mathrm{T}_{\text {critical }}($ alpha $=0.05)$ & 18.4 & 0.59 & $\mathrm{NS}^{\mathrm{e}}$ & NS & 15.4 & 0.56 & 256 & NS \\
\hline
\end{tabular}

${ }^{a}$ Stand counts 21 days after planting expressed as percent seed planted.

${ }^{\mathrm{b}}$ Incidence of loose smut expressed as percent of stand.

${ }^{c}$ Yield in kilograms per hectare.

${ }^{\mathrm{d}}$ Percent visually scabby kernels in harvested grain estimated using visual comparison standards (16).

${ }^{\mathrm{e}}$ Not significant. 
ally scabby kernels (\% VSK) in harvested grain was estimated from two 50-g subsamples using visual comparison standards (16).

\section{RESULTS}

Seed lot quality varied between lot 920071 (hereafter referred to as lot 92) and lot 93-4843 (hereafter referred to as lot 93). Lot 92 contained 27,234 seed per $\mathrm{kg}$, had a test weight of $938 \mathrm{~kg} \mathrm{~m}^{-3}$, and contained less than 1\% VSK (Table 1). In HPLC tests performed six times (16), lot 92 was found to contain no detectable deoxynivalenol, a secondary metabolite of $F$. graminearum (16) that is stable in storage. Lot 92 contained $1.7 \%$ Fusarium-infected kernels and exhibited $98.5 \%$ germination on blotter tests (Table 3). In contrast, lot 93 contained 29,646 seed per $\mathrm{kg}$, had a test weight of $840 \mathrm{~kg} \mathrm{~m}^{-3}$, and contained $24.2 \%$ VSK (Table 1). In tests performed six times, samples of lot 93 were found to contain $16.6+/-1.4 \mu \mathrm{g}$ of deoxynivalenol per gram. Lot 93 averaged $70 \%$ Fusariuminfected kernels and germinated at $40 \%$ (Table 3). Both lot 92 and lot 93 contained other Fusarium spp. at $<1.0 \%$ and Bipolaris sorokiniana at $<1.0 \%$ and were selected for use, in part, as a result of this finding. Surface-sterilization of seed of lot 93 reduced the percent infected kernels to $62 \%$ and increased germination in the blotter tests to $72 \%$ (Table 3 ).

Germination and vigor tests. Plants were established from $98 \%$ of unsterilized seed and $97 \%$ of surface-sterilized seed of lot 92 (Table 3). Seed of lot 93 emerged more slowly than seed of lot 92 . At 7 days after sowing, only $34 \%$ of unsterilized seed and $45 \%$ of surface-sterilized seed had emerged. Plants in these treatments began to die of seedling blight during the next 14 days, even as some additional emergence continued. By 21 days after planting, seedling blight reached a maximum, and plant loss was not observed between 21 and 28 days, when the experiments were terminated (Table 3). Surviving plants in all treatments remained healthy and normal in size and color. Plant counts in lot 92 averaged 98 and $97 \%$ of sown seed in unsterilized and surface-sterilized treatments, respectively (Table 3). Plant counts in lot 93 averaged 46 and $68 \%$ of sown seed in unsterilized and surface-sterilized treatments, respectively (Table 3 ). The dry weight of harvested plants established from unsterilized seed lots averaged $2.543 \mathrm{~g}$ per pot and $0.026 \mathrm{~g}$ per plant for lot 92 and $1.155 \mathrm{~g}$ per pot and $0.025 \mathrm{~g}$ per plant for lot 93 (Table 3 ). Seed that had been surface-sterilized averaged $2.432 \mathrm{~g}$ per pot and $0.025 \mathrm{~g}$ per plant for lot 92 and $1.632 \mathrm{~g}$ per pot and $0.024 \mathrm{~g}$ per plant for lot 93 (Table 3). $t$ tests identified significant differences $(P<$ 0.01 ) between the dry weights on a per pot basis in both untreated and surface-sterilized comparisons (lot 92 compared with lot 93), but paired comparisons of the dry weights on a per plant basis were not statistically different (Table 3 ).

Field tests. Stands that developed from plantings of untreated seed of the Fusarium-damaged lot 93 were affected by seedling blight at each location. Emergence was delayed slightly, and soon after emergence, seedlings began to exhibit chlorosis and die. Stand loss continued over the next 10 days and ceased approximately 14 to 18 days after planting. At 21 days after planting, plant populations derived from untreated seed of lot 93 were uniformly thinned due to seedling blight losses (Fig. 1). The mean number of surviving plants per $\mathrm{m}^{2}$ of lot 93 were $270,224,137$, and 124 for the four respective sites of Roseau, Crookston PD1, Crookston PD2, and Morris. The variance to mean ratios of individual plant counts $(\mathrm{n}=36$; six observations per replicate, six replicates) were 2.04 , $1.45,1.06$, and 1.07, respectively. This suggests that the distribution of seedling blight within plots can be characterized as random, as opposed to clustered.

Plant counts of 21-day-old seedlings that developed from untreated seed of the Fusarium-damaged lot 93 varied from $66 \%$ (Roseau) to $30 \%$ (Morris). Soil temperatures $(10 \mathrm{~cm}$ depth) for the 10 consecutive days after planting averaged 11.3 and $19.3^{\circ} \mathrm{C}$, respectively, at these locations. At Crookston, untreated seed of lot 93 averaged 54\% stand when planted 20 April and $33 \%$ when planted 5 May (Table 2). Soil temperatures $(10 \mathrm{~cm}$ depth) for 10 days

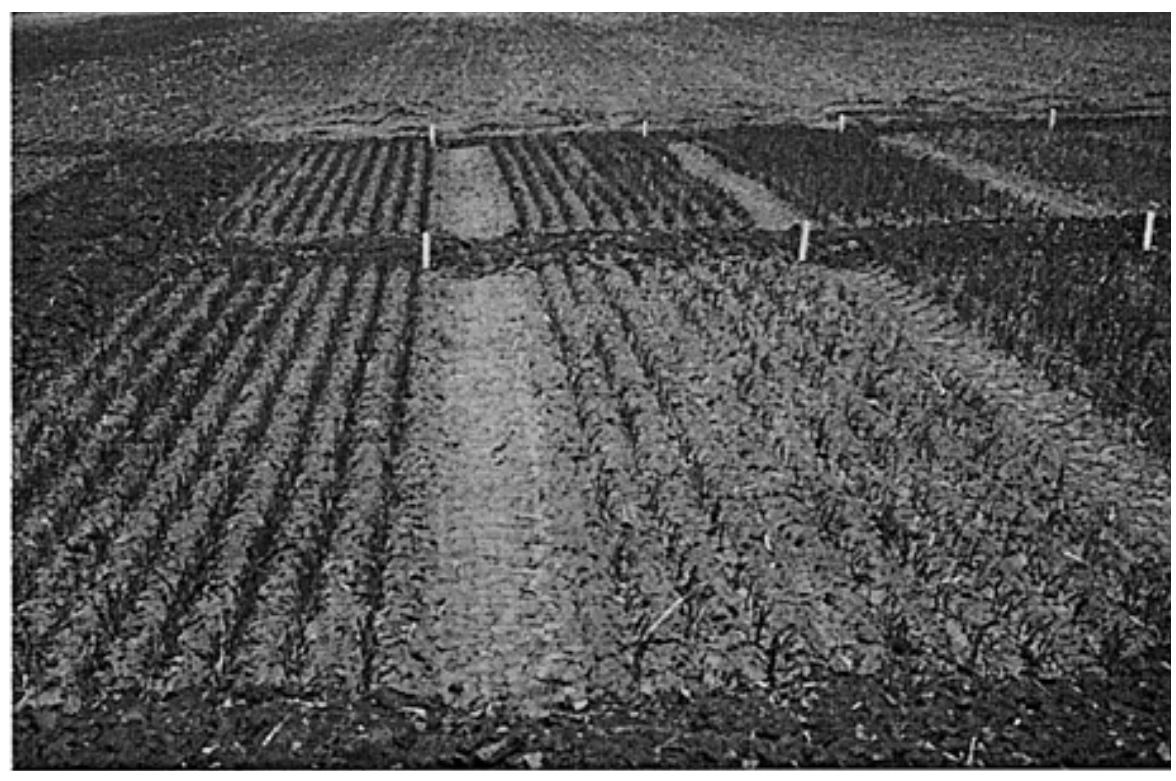

Fig. 1. Stand of spring wheat photographed 1 June (21 days after planting) at Crookston, Minn. Foreground left, untreated seed of lot 92 (undamaged seed lot); center, untreated seed of lot 93 (Fusarium-damaged seed lot); and extreme right, untreated seed of lot 93 treated with DB-Green L. Background left, lot 92 treated with Vitavax-Extra; left center, DB-Green L; right center, untreated; and right, lot 93 untreated.

Table 3. Seed quality of Fusarium-damaged and undamaged seed lots of spring wheat ${ }^{\mathrm{a}}$

\begin{tabular}{|c|c|c|c|c|c|c|c|c|c|}
\hline \multirow[b]{2}{*}{ Treatment } & \multirow[b]{2}{*}{ Seed lot } & \multirow[b]{2}{*}{ Infection $(\%)^{\mathbf{b}}$} & \multirow[b]{2}{*}{ Germ. $(\%)^{\mathrm{c}}$} & \multicolumn{4}{|c|}{ Plants emerged $(\%)^{d}$} & \multicolumn{2}{|c|}{ Dry weight } \\
\hline & & & & $7 d$ & 14d & 21d & 28d & g/pot & g/plant \\
\hline \multirow[t]{3}{*}{ Untreated } & $93-4843$ & 69.7 & 40.5 & 34.4 & 55.8 & 46.2 & 46.2 & 1.155 & 0.025 \\
\hline & $92-0071$ & 1.7 & 98.5 & 66.3 & 97.8 & 97.8 & 97.8 & 2.543 & 0.026 \\
\hline & $P$ value from $t$ test & $<0.001$ & $<0.001$ & $<0.01$ & $<0.01$ & $<0.01$ & $<0.01$ & $<0.01$ & 0.712 \\
\hline \multirow{3}{*}{$\begin{array}{l}\text { Surface- } \\
\text { sterilized }^{\text {e }}\end{array}$} & $93-4843$ & 62.3 & 72.0 & 45.4 & 74.5 & 68.2 & 68.0 & 1.632 & 0.024 \\
\hline & $92-0071$ & 0.7 & 99.3 & 67.0 & 95.7 & 97.2 & 97.2 & 2.432 & 0.025 \\
\hline & $P$ value from $t$ test & $<0.001$ & $<0.001$ & $<0.01$ & $<0.01$ & $<0.01$ & $<0.01$ & $<0.01$ & 0.689 \\
\hline
\end{tabular}

a Values are based on six replicates of 100 seeds.

${ }^{\mathrm{b}}$ Seed incubated on potato dextrose agar for 7 days at $24^{\circ} \mathrm{C}$.

${ }^{\mathrm{c}}$ Seed incubated on blotters 7 days at $24^{\circ} \mathrm{C}$.

${ }^{\mathrm{d}}$ Seed grown in steam-sterilized soil for 28 days at $22^{\circ} \mathrm{C}$

e Sterilized in $95 \%$ ethanol $(5 \mathrm{~s})$ and in $0.5 \% \mathrm{NaOCl}(1 \mathrm{~min})$, rinsed in sterile water, and dried. 
after planting averaged 12.2 and $21.2^{\circ} \mathrm{C}$ for the respective planting dates.

Seed of lot 93 treated with Vitavax-Extra produced stands that averaged $83 \%$ of the estimated seed planted (an increase of $37 \%$ compared with the mean of $46 \%$ for untreated seed of this lot). Treatment with DB-Green L resulted in stands that averaged $82 \%$ of seed planted (an increase of $36 \%$ ) across all sites. Seed of lot 93 treated with DB-Green L plus Agsco RR (containing $10 \%$ imazalil) resulted in stands of $80 \%$ across all sites or $1.8 \%$ less than DBGreen L alone. Seed of lot 93 treated with Dividend (difenoconazole) at a rate of 0.32 $\mathrm{ml} / \mathrm{kg}$ resulted in stands that averaged $71 \%$ of seed planted. Dividend was significantly $(P=0.05)$ less effective than Vitavax-Extra or DB-Green $\mathrm{L}$ when planting was delayed, and stand loss due to seedling blight was high (11 May planting date at Crookston [Table 2] and 11 May planting at Morris [Table 4]). When soil temperatures were lower (20 April planting date at Crookston [Table 2] and 3 May planting date at Roseau [Table 5]), stand counts were lower in Dividend treatments compared with Vitavax-Extra or DB-Green
L, but differences were not statistically different $(P=0.05)$. Seed treatments containing fenbuconazole (AG-4452) and tetraconazole (AG-4454) improved stands derived from the Fusarium-damaged lot 93 compared with untreated seed, but in the 11 May planting at Crookston, they were less effective than Vitavax-Extra or DBGreen L (Table 2). The higher rate of the triazole-type fungicides consistently produced higher stand counts than the lower rate, but in no case were these differences statistically significant $(P=0.05)$.

Plant populations that developed from the undamaged-uninfected lot 92 averaged $99 \%$ of the sown seed without any fungicide treatment (Tables 2 and 5). Lot 92 treated with Vitavax-Extra averaged 95\% and treated with DB-Green L averaged 93\%. In an independent analysis of variance, the reductions in plant population associated with the treatment of healthy seed (lot 92) were statistically significant $(P=0.05)$.

The incidence of loose smut in untreated plantings of lot 93 was $1.9 \%$ across all locations (Tables 2, 4, and 5). VitavaxExtra, Dividend, and the experimental

Table 4. Influence of seed treatments on stand, loose smut, yield, and percent visually scabby kernels in spring wheat planted 11 May 1994, West Central Experiment Station, Morris, Minn.

\begin{tabular}{|c|c|c|c|c|}
\hline Treatment (ml/kg) & Stand $(\%)^{\mathrm{a}}$ & Smut $(\%)^{\mathbf{b}}$ & Yield $^{c}$ & $\operatorname{VSK}(\%)^{\mathrm{d}}$ \\
\hline Vitavax-Extra (1.95) & 88.6 & 0.00 & 2,609 & 10.0 \\
\hline DB-Green L (3.24) & 82.9 & 1.61 & 2,562 & 11.6 \\
\hline \multicolumn{5}{|l|}{ DB-Green L (3.24) } \\
\hline + Agsco RR (0.43) & 79.6 & 0.81 & 2,636 & 11.3 \\
\hline Dividend (0.16) & 58.4 & 0.00 & 2,117 & 12.5 \\
\hline Dividend (0.32) & 64.0 & 0.00 & 2,199 & 12.5 \\
\hline Untreated lot 93 & 30.1 & 1.85 & 1,730 & 15.8 \\
\hline $\mathrm{T}_{\text {critical }}(\mathrm{alpha}=0.05)$ & 10.9 & 0.43 & 350 & 4.2 \\
\hline
\end{tabular}

${ }^{a}$ Stand counts 21 days after planting expressed as percentage of seed planted.

${ }^{\mathrm{b}}$ Incidence of loose smut expressed as percentage of stand.

$c$ Yield in kilograms per hectare.

${ }^{\mathrm{d}}$ Percent visually scabby kernels in harvested grain estimated using visual comparison standards (16).

Table 5. Influence of seed treatments on stand, loose smut, yield, and percent visually scabby kernels in spring wheat planted 3 May 1994, West Plant Research Farm, Roseau, Minn.

\begin{tabular}{|c|c|c|c|c|}
\hline Treatment (ml/kg) & Stand $(\%)^{\mathrm{a}}$ & Smut $(\%)^{\mathbf{b}}$ & Yield $^{\mathrm{c}}$ & $\operatorname{VSK}(\%)^{\mathrm{d}}$ \\
\hline Vitavax-Extra (1.95) & 81.2 & 0.00 & 2,595 & 15.3 \\
\hline DB-Green L (3.24) & 83.4 & 1.88 & 2,716 & 17.0 \\
\hline \multicolumn{5}{|l|}{ DB-Green L (3.24) } \\
\hline + Agsco RR (0.43) & 80.5 & 0.63 & 2,710 & 16.6 \\
\hline Dividend (0.16) & 78.0 & 0.00 & 2,736 & 17.8 \\
\hline Dividend (0.32) & 80.8 & 0.00 & 2,474 & 16.3 \\
\hline Agsco-4452 (3.24) & 76.6 & 0.02 & 2,777 & 18.0 \\
\hline Agsco-4452 (4.54) & 76.9 & 0.00 & 2,750 & 18.0 \\
\hline Agsco-4454 (1.62) & 77.5 & 0.03 & 2,757 & 15.4 \\
\hline Agsco-4454 (3.24) & 77.3 & 0.00 & 2,676 & 15.9 \\
\hline Untreated lot 93 & 65.5 & 2.17 & 2,703 & 18.0 \\
\hline Vitavax-Extra lot 92 (1.95) & 98.6 & 0.00 & 3,012 & 16.6 \\
\hline DB-Green L lot 92 (3.24) & 96.1 & 0.80 & 2,992 & 17.0 \\
\hline Untreated lot 92 & 102.7 & 0.82 & 3,052 & 15.4 \\
\hline $\mathrm{T}_{\text {critical }}($ alpha $=0.05)$ & 21.6 & 0.64 & $\mathrm{NS}^{\mathrm{e}}$ & NS \\
\hline
\end{tabular}

a Stand counts 21 days after planting expressed as percentage of seed planted.

${ }^{\mathrm{b}}$ Incidence of loose smut expressed as percentage of stand.

$c$ Yield in kilograms per hectare.

${ }^{\mathrm{d}}$ Percent visually scabby kernels in harvested grain estimated using visual comparison standards (16).

${ }^{\mathrm{e}}$ Not significant. triazole-type fungicides (fenbuconazole and tetraconazole) effectively controlled loose smut. Seed treated with DB-Green L averaged $1.9 \%$ smutted plants and was not statistically different than untreated seed at any of the sites. Lot 92 averaged $0.65 \%$ smutted plants (Tables 2 and 5). VitavaxExtra controlled loose smut in plantings of this lot, and DB-Green L was ineffective (Tables 2 and 5).

FHB developed in all experiments. Symptoms were evident as grain development approached Feekes growth stage 11.2 (soft dough stage). In harvested grain, the \%VSK varied by location and was not related to the amount of seedling blight (Tables 2, 4, and 5). At Crookston, the 20 April planting date averaged $36.8 \%$ VSK and the 11 May planting date averaged $36.1 \%$ (Table 2). At Roseau, planted 3 May, FHB was less and treatments averaged $16.7 \%$ VSK. Within sites, the \%VSK tended toward an inverse relationship with percent stand, but there were no significant differences $(P=0.05)$ among treatments for $\% \mathrm{VSK}$ at these locations. At Morris, planted 11 May, the untreated plots averaged $15.7 \%$ VSK, and treatment with Vitavax-Extra or DB-Green L significantly $(P=0.05)$ reduced the \%VSK in harvested grain (Table 4).

The yield of harvested grain was severely affected by FHB at Crookston. Treatments planted 20 April averaged $1,451 \mathrm{~kg} / \mathrm{ha}$, and there were no significant differences $(P=0.05)$ among treatments (Table 2). In the second planting, yields ranged from 1,143 to $659 \mathrm{~kg} / \mathrm{ha}$, and several treatments produced stands that resulted in yields that were statistically greater $(P=0.05)$ than the yield from untreated seed of lot 93 (Table 2). The yield of untreated lot $92(1,095 \mathrm{~kg} / \mathrm{ha})$ was also significantly greater $(P=0.05)$ than that of untreated lot 93 (Table 2), suggesting that these effects may have been a result of plant population. At Roseau, yields from harvested plots ranged from 3,052 to 2,474 $\mathrm{kg} / \mathrm{ha}$ (Table 5). There were no statistically significant differences $(P=0.05)$ among treatments. At Morris, the yield of plots planted with untreated seed of lot 93 was $1,730 \mathrm{~kg} / \mathrm{ha}$ (Table 4). The yields of all treatments were statistically greater $(P=$ $0.05)$ than those from untreated seed.

\section{DISCUSSION}

The activity of $F$. graminearum in standard blotter tests is a major difficulty facing seed testing services. Results reported in this study suggest that germination and vigor tests conducted at higher temperatures $\left(22\right.$ to $\left.24^{\circ} \mathrm{C}\right)$, coupled with determinations of percent seed infection, are useful indicators of seedling blight potential. However, the degree of postemergence seedling blight that develops in field plantings of Fusarium-damaged seed is strongly influenced by soil temperatures at and during emergence. Infected seed lots 
can produce satisfactory stands with the use of an effective seed treatment. As a result of this investigation, the Minnesota Crop Improvement Association has adopted a protocol to conduct germination tests on Fusarium-damaged seed lots both with and without Vitavax-Extra. This information is then reported to the grower and is used in the decision-making process with regard to seed treatment. Spring wheat producers utilizing germination and vigor tests are encouraged to have these tests conducted as close as possible to the actual time of planting, as infection frequency declines over time due to a loss of viability of the fungus within seed $(5,13)$.

The response of Fusarium-damaged seed lots to seed treatment will vary depending on the degree of damage and the association or disassociation of damage with seed sizes that can be removed by special cleaning operations, including gravity tables (30). Germination test results suggest that only $40 \%$ of the seed in lot 93 were viable; yet effective seed treatments produced plants from approximately $90 \%$ of these seed when they were planted in the field. Current Extension Service recommendations are to thoroughly clean Fusarium-damaged seed using gravity tables, then treat with an effective fungicide, to increase the seeding rate at planting by $10 \%$ (15). These recommendations appear sound if disease-free seed is unavailable. Adjustments in seeding rate should correctly compensate for stand losses caused by this seedborne fungus. Refining this adjustment on a percentage basis may prove difficult. The adjustment cannot be directly estimated from the results of germination tests. It may be more accurately modeled from soil temperature information if seed infection information is available.

The stand loss resulting from planting seed infected with $F$. graminearum group 2 is characterized by both a germination failure and a postemergence seedling blight. The degree of postemergence seedling blight can be reduced by an effective seed treatment. The rank order of seed treatment performance in the experiments reported here was consistent across all plantings. Thiabendazole and maneb were the most effective fungicides tested. Difenoconazole was intermediate, and fenbuconazole and tetraconazole were less effective. Loose smut was controlled by the systemic fungicide carboxin and all of the triazoletype fungicides tested. Maneb seed treatments were ineffective against loose smut. Across four sites, the addition of imazalil failed to improve stands of Fusarium-damaged wheat compared with maneb alone. The average stand from Fusarium-damaged seed of lot 93 treated with DB-Green L was $77.3 \%$ compared with $75.6 \%$ for DB-Green $\mathrm{L}+$ Agsco RR. This suggests that imazalil contributes little to control of seedborne $F$. graminearum.
Late planting increased the benefits from seed treatment. This contradicts Extension Service recommendations in which seed treatments were thought to be needed most when planting into cold, wet soils (26). $F$. graminearum is more active in warm versus cool soils (9). Cleaning and conditioning seed, increasing seeding rates, and treating seed with an effective fungicide appear to be sound recommendations when Fusarium-damaged seed lots must be used. These recommendations may be more important for spring wheat producers (who are planting in conditions when soil temperatures are likely to warm), as opposed to winter wheat producers, who often plant in conditions where soil temperatures may be expected to cool as seeding is delayed.

Ocamb and Kommedahl $(24,25)$ described $F$. graminearum group 2 as rhizosphere incompetent. Yet Nyvall (23) reported that chlamydospores formed and survived in excess of 16 months in nonautoclaved field soil. Results reported here indicate that under field conditions, the seedborne inoculum associated with stand loss attributable to $F$. graminearum group 2 is more important than soilborne inoculum. Stand loss associated with a healthy seed lot averaged 3\% planted immediately adjacent to plantings where stand loss exceeded $67 \%$ (Fig. 1). In addition, the distribution of seedling blight appeared to be random and uniform within each location. This also suggests that seed and not soil represented the primary source of inoculum. The lack of rhizosphere competence may also account for the observed activity of protectant fungicides like maneb against $F$. graminearum group 2. F. culmorum and $F$. graminearum group 1 survive longer in soil (28). The crown rot fungi may be more rhizosphere competent, and systemic seed treatments could have advantages when these fungi are involved (21,31).

Seedling blight affected yield in the second planting date at Crookston (Table 2) and at Morris (Table 4). Plant populations at these locations fell below 113 plants per $\mathrm{m}^{2}$. Populations of spring wheat plants that fall below this level cannot compensate for stand loss with tillering and are considered candidates for replanting (26). Other plant population effects have been observed to be associated with stands reduced by seedling blight. These include an increase in populations of grassy weeds, particularly green foxtail (Setaria viridus), that become more competitive in spring wheat stands that are thinned by seedling blight.

FHB developed in each of the field trials, but the severity of the disease varied with factors other than the amount of seedling blight, including the amount of rainfall and the number of rain-day events during anthesis (32). The cultivar Norm is considered highly susceptible to FHB, and disease severity is directly proportional to the percentage of VSK for this cultivar (16).
FHB was most severe at Crookston (20 April planting and 11 May planting), least severe at Morris, and intermediate at Roseau. There was no evidence of seed transmission of the head blight phase of this disease in these studies.

Halfon-Meiri et al. (14) observed perithecia of $G$. zeae on dying seedlings grown in sterilized sand culture. Dickson (9) observed that perithecia form on the culm of diseased seedlings near the soil line of field-grown plants. Although diseased tissues were not examined for formation of perithecia in this study, it would be of interest to know if blighted seedlings are capable of functioning as a source of primary inoculum for the head blight phase of this disease. If so, it may explain observed outbreaks of FHB in fields that were rotated the previous year to nonhost crops and would also suggest an additional benefit from seed treatment if the treatment is able to eliminate this inoculum source.

\section{ACKNOWLEDGMENTS}

This study was made possible through the efforts of many individuals. Special thanks are extended to Larry J. Smith, Northwest Experiment Station, Crookston; Carlyle Holen, University of Minnesota Extension Service, Crookston; and Sandee Gould, Department of Plant Pathology, University of Minnesota, St. Paul. Published as paper $981,220,050$ of the contribution series of the Minnesota Agriculture Experiment Station based on research conducted under Project 22-38.

\section{LITERATURE CITED}

1. Analytical Software Group. 1996. Statistix for Windows. Analytical Software, Tallahassee, FL.

2. Association of Official Seed Analysts. 1981 Rules for testing seeds. J. Seed Technol. 3:50.

3. Atanasoff, D. 1920. Fusarium blight (scab) of wheat and other cereals. J. Agric. Res. (U.S.) 20:1-32.

4. Bechtel, D. B., Kaleikau, L. A., Gaines, R. L., and Seitz, L. M. 1985. The effects of Fusarium graminearum infection on wheat kernels. Cereal Chem. 62:191-197.

5. Bergstrom, G. 1993. Scab (Fusarium Head Blight). Pages 83-93 in: Seed-borne Diseases and Seed Health Testing of Wheat. S. B. Mathur and B. M. Cunfer, eds. Danish Government Institute of Seed Pathology for Developing Countries. Jordbrugsforlaget, Fredriksberg, Denmark.

6. Buechley, G., Lehman, J., and Shaner, G. 1988. Effect of seed treatment on stand establishment from scabby wheat. Fungic. Nematicide Tests 44:220.

7. Buechley, G., and Shaner, G. 1987. Effect of seed treatment on stand establishment from scabby seed. Fungic. Nematicide Tests 43:241.

8. Cook, R. J. 1981. Fusarium diseases of wheat and other small grains in North America. Pages 39-52 in: Fusarium: Diseases, Biology and Taxonomy. P. E. Nelson, T. A. Toussoun, and R. J. Cook, eds. Pennsylvania State University, University Park.

9. Dickson, J. G. 1923. Influence of soil temperature and moisture on the development of the seedling blight of wheat and corn caused by Gibberella saubinetii. J. Agric. Res. (U.S.) 23:837-870.

10. Dickson, J. G., and Mains, E. B. 1929. Scab of wheat and barley and its control. U.S. Dep. Agric. Farmers Bull. 1599 (revised):1-22.

11. Francis, R. G., and Burgess, L. W. 1977. 
Characteristics of two populations of Fusarium roseum 'graminearum' in Eastern Australia. Trans. Br. Mycol. Soc. 68:421-427.

12. Gilbert, J., and Tekauz, A. 1995. Effects of fusarium head blight and seed treatment on germination, emergence, and seedling vigour of spring wheat. Can. J. Plant Pathol. 17:252259.

13. Gilbert, J., Tekauz, A., and Woods, S. M. 1997. Effect of storage on viability of Fusarium head blight-affected spring wheat seed. Plant Dis. 81:159-162.

14. Halfon-Meiri, A., Kulik, M. M., and Schoen, J. F. 1979. Studies on Gibberella zeae carried by wheat seeds produced in the Mid-Atlantic region of the United States. Seed Sci. Technol. 7:439-448.

15. Jones, R. K. 1994. Managing Fusarium head scab for 1995. Minnesota Extension Service, University of Minnesota, St. Paul. Plant Pest Newsl. PPST 17:100-102.

16. Jones, R. K., and Mirocha, C. J. 1999. Quality parameters in small grains from Minnesota affected by Fusarium head blight. Plant Dis. 83:506-511.

17. Large, E. C. 1954. Growth stages in cereals. Illustrations of the Feekes scale. Plant Pathol. 3:128-129.

18. Martin, R. A., and Johnston, H. W. 1982. Effects and control of fusarium diseases of cereal grains in the Atlantic Provinces. Can. J. Plant Pathol. 4:210-216.

19. McMullen, M., Jones, R., and Gallenberg, D. 1997. Scab of wheat and barley: A re-emerging disease of devastating impact. Plant Dis. 81:1340-1348
20. McMullen, M. P., and Stack, R. W. 1987. Improved wheat and durum seedling stands and vigor by fungicide seed treatments. N.D. Farm Res. 45:13-15.

21. Mihuta-Grimm, L., and Forster, R. L. 1989. Scab of wheat and barley in Southern Idaho and evaluation of seed treatments for eradication of Fusarium spp. Plant Dis. 73:769-771.

22. Nelson, P. E., Toussoun, T. A., and Marasas, W. F. O. 1983. Fusarium species. An Illustrated Manual for Identification. Pennsylvania State University, University Park.

23. Nyvall, R. F. 1970. Chlamydospores of Fusarium roseum 'graminearum' as survival structures. Phytopathology 60:1175-1177.

24. Ocamb, C. M., and Kommedahl, T. 1994. Rhizosphere competence of Fusarium species colonizing corn roots. Phytopathology 84:166-172.

25. Ocamb, C. M., and Kommedahl, T. 1994. Growth of rhizosphere competent and incompetent Fusarium species from corn on carbon substrates. Phytopathology 84:508-514

26. Oelke, E. A., Durgan, B. R., Cavanaugh, K. J., Jones, R. K., Noetzel, D. M., Rehm, G. W., and Wilcke, W. F. 1993. Hard Red Spring Wheat \& Spring Barley Production Guide. AG-MI-5868-F. Minnesota Extension Service, University of Minnesota, St. Paul

27. Popp, W. 1951. Infection in seeds and seedlings of wheat and barley in relation to development of loose smut. Phytopathology 41:261-275.

28. Sitton, J. W., and Cook, R. J. 1981. Comparative morphology and survival of chlamydo- spores of Fusarium roseum 'Culmorum' and 'Graminearum'. Phytopathology 71:85-90.

29. Specht, L. P., and Rush, C. M. 1988. Fung associated with root and foot rot of winter wheat and populations of Cochliobolus sativus in the Texas Panhandle. Plant Dis. 72:959-963.

30. Tkachuk, R., Dexter, J. E., Tipples, K. H., and Nowicki, T. W. 1991. Removal by specific gravity table of tombstone kernels and associated trichothecenes from wheat infected with Fusarium head blight. Cereal Chem. 68:428 431.

31. Uoti, J. 1976. Study of control of seed-borne Fusarium in cereals. Ann. Agric. Fenn. 18:149-153.

32. Wiersma, J. V., Peters, E. L., Hanson, M. L., Bouvette, R. J., and Busch, R. H. 1996. Fusarium head blight in hard red spring wheat: Cultivar responses to natural epidemics. Agron. J. 88:223-230.

33. Wilcoxson, R. D., Kommedahl, T., Ozmon, E A., and Windels, C. E. 1988. Occurrence of Fusarium species in scabby wheat from Minnesota and their pathogenicity to wheat. Phytopathology 78:586-589.

34. Windels, C. E., and Holen, C. 1989. Association of Bipolaris sorokiniana, Fusarium graminearum group 2, and $F$. culmorum on spring wheat differing in severity of common root rot. Plant Dis. 73:953-956.

35. Windels, C. E., and Wiersma, J. V. 1992 Incidence of Bipolaris and Fusarium on subcrown internodes of spring barley and wheat grown in continuous conservation tillage. Phytopathology 82:699-705. 